\title{
Environment, Technology, and Health
}

Human Ecology in Historical Perspective 


\title{
Environment, \\ Technology, and Health Human Ecology in Historical Perspective
}

\author{
Merril Eisenbud
}

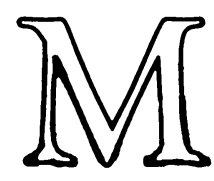


(C) New York University 1978

Softcover reprint of the hardcover 1st edition 1978 978-0-333-26933-6

All rights reserved. No part of this publication may be reproduced or transmitted, in any form or by any means, without permission

First published in the United States of America 1978

First published in the United Kingdom 1979

Published by

THE MACMILLAN PRESS LTD

London and Basingstoke

Associated companies in Delhi

Dublin Hong Kong Johannesburg Lagos

Melbourne New York Singapore Tokyo

British Library Cataloguing in Publication Data

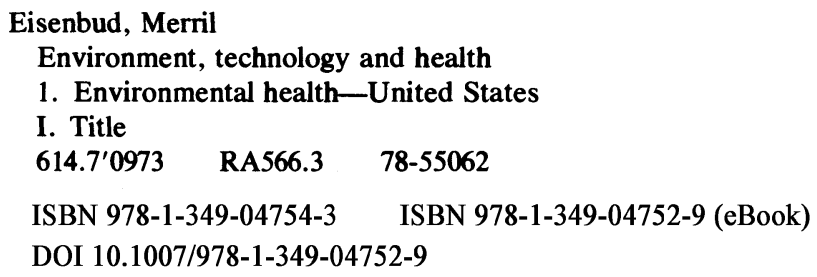

This book is sold subject to the standard conditions of the Net Book Agreement 


\section{Contents}

Preface $\quad$ ix

Part I SETTING THE STAGE 1

1 What Is the Environment Movement? 3

2 The Preindustrial Centuries 13

3 The Industrial Revolution 34

4 The Twentieth Century: The Evolution of
Environmental Policy

Part II PEOPLE, ENERGY, AND RESOURCES:

CAN WE KEEP THEM IN BALANCE?

5 Population Growth, Food, Energy, and Raw Materials $\quad 79$

6 Energy Supply and Demand 116

Part III ENVIRONMENTAL CONTAMINATION: SOME CONTEMPORARY ISSUES

7 Some General Principles 167

8 Environmental Cancer $\quad 186$

9 The Organic Chemicals $\quad 227$

10 The Metals: Lead and Mercury 247

Sulfur Oxides and Particulates from the
Combustion of Coal and Oil

12 Air Pollution from Automobiles 288 
viii

Contents

13 Nuclear Power 305

14 Some Long-Range Atmospheric Effects of Pollution 336

Part IV WHERE ARE WE, AND WHERE ARE WE GOING? 349

15 The Environmental Movement and Human Health: An Overall Appraisal

Subject Index

Author Index 


\section{Preface}

The surge of public interest in environmental matters that developed in the 1960s was a welcome development to those who, like this writer, had already labored professionally for decades in the environmental field. It was satisfying to know that government officials, the general public, and the electronic and printed media had at last recognized the need to control pollution, rehabilitate spoiled land, and preserve wild life.

Much has since been accomplished. The National Environmental Policy Act, the Occupational Health and Safety Act, and the Toxic Substances Control Act are only a few of the many important laws that have come into being during the past decade and which have provided the basic legal and administrative machinery by which environmental control can be achieved. Billions of dollars have been appropriated for environmental protection and rehabilitation, and public interest remains high, as evidenced by the continuing attention given the subject in the daily press and other media.

However, there is also reason for disappointment. The subject of "environment" has become highly politicized. Discussions take place in an atmosphere of advocacy in which complex issues tend to be described in terms of black and white, rather than in the required shades of gray.

This book is an appraisal of the contemporary environmental movement insofar as public health is concerned. The subject is so ramified that it is not possible to examine all of the important issues in a single volume. However, the subjects that have been selected for discussion have been chosen in order to illustrate the reasons for the inherent complexity of environmental issues.

As is true in other fields of knowledge, an understanding of the past assists one to understand the present and plan for the future. It is for this reason that so much of this book is concerned with the history of the human environment.

I am indebted to many colleagues and organizations for assistance 
during preparation of this book. The broad coverage of the subject matter required efficient library support, for which I thank Mrs. Christine Singleton, Assistant Curator of the New York University Medical Center Library, and the staff of the Tuxedo Public Library.

It is also a pleasure to acknowledge my indebtedness for many hours of stimulating discussions with colleagues and friends who reviewed portions of the book. Among these were David Axelrod, Joseph Delibert, Leonard Goldwater, Marvin Kuschner, Morton Lippmann, Jacqueline Messite, Joseph O'Connor, Lin Root, Arthur Stern, and Guenther Stotzky. I am also appreciative to Nat LaMar, who edited my manuscript with insight and helped to structure it into final form. I acknowledge the assistance of these and other colleagues and friends, but in no way do I wish to dilute the responsibility an author must assume for the material presented.

Roger Sparling prepared the illustrations, and my assistant, Eleanor Clemm, was invaluable in an editorial capacity and in coordinating the extensive library work required, as well as by typing every word of the four to six drafts from which the final manuscript of this book evolved.

\section{Merril Eisenbud}

New York University

September 1978 